\title{
Fair Value Accounting Perspectives, Adoption and Implementation Patterns for Preparers and Users in One Southern African Economy
}

\author{
Job Dubihlela \\ Vaal University of Technology, Faculty of Management Sciences \\ Private Bag X021, Vanderbijpark 1900 South Africa \\ email: job@vut.ac.za
}

Dennis Sibanda

Vaal University of Technology, Faculty of Management Sciences Private Bag X021, Vanderbijlpark 1900 South Africa

\section{Doi:10.5901/mjss.2014.v5n8p52}

\section{Abstract}

This study examines the definition and understanding of 'fair value accounting', and identifies how it is measured in Zimbabwe at the back of the most recent financial crisis which prompted strong debates about the pros and cons of fair-value accounting (FVA). The debate presents a major challenge for FVA going forward as standard setters' push to extend FVA into other areas of accounting valuations. The study also explores benefits and limitations of the concept, examining its impact on financial reporting roles, determines appropriate alternatives to this method and forecasts its prominence and endurance in Zimbabwe. The paper concludes that users and preparers of financial reports have similar understanding of fair value accounting. Some benefits identified were better disclosure and information that is more relevant. Limitations of the method in terms of costs of valuation, training and hiring of professionals, and the application of subjective judgment were identified. The proxies predicted prominence of fair value accounting in the long run. Thus, we recommended certain fair-value accounting and disclosures be considered.

Keywords: Fair value accounting, measurement techniques, valuation method, Zimbabwe

\section{Introduction}

In recent years, Fair Value Accounting (FVA) has made substantial headway in news outlets as it has been a popular element at the forefront of current accounting issues. Even after the financial crisis, usage patterns of fair value accounting has been frowned upon igniting the debate amongst accounting professionals. In reality, fair value accounting and quality of earnings are subjects that always trigger interest, particularly in the Zimbabwean environment. With FVA becoming an essential feature of International Financial Reporting Standards (IFRS) (Kaplan, 2011), accounting for assets and liabilities at market prices can produce results that sometimes dramatically change the underlying dynamics for certain businesses and activities (ICAZ, 2010), particularly during volatile and uncertain economic and market conditions (Bernanke, Ben \& Gertler, 1999) such as prevailing in Zimbabwe. The limitations inherent in fair-value accounting do not detract from the usefulness of fair-value measurements in providing a consistent starting point in analyzing financial statements (Ratcliffe, 2007). The imperfect nature of FVA underscores the need for financial statements to be complemented with additional information about uncertainties in the measurement of assets and liabilities.

Accounting systems provide a source of information to owners and managers operating in any industry for use in the measurement of financial performance. The concept of FVA emerged to cover gaps existing in the historical cost accounting (Holt, 2008). Historical cost accounting has co-existed with major corporate collapses and tremendous pressure from users of financial reports prompting the Financial Accounting Standards Board (FASB) and International Accounting Standards Board (IASB) to refocus attention from historical cost accounting towards FVA (Rayman, 2007). The world at large is affected by this move in one way or another. In the face of Zimbabwe being such a volatile economy, FVA has found its way there. Therefore, it is essential to consider 'FVA' in Zimbabwe's context.

The purpose of this study was to explore the definition and understanding of 'FVA' in Zimbabwe, identify how fair value is measured in this inflationary economy with a very sizeable market (for shares and property investments). The 
study further ascertains the benefits and limitations associated with this accounting phenomenon and touch on the perceived roles of financial reports. It also considers alternatives of this method and forecasts the prominence and endurance of FVA.

\section{Literature Review}

The crusade for fair value began in 1997 when accounting bodies from America, Australia, Britain, Canada and New Zealand set up a working group to discuss international accounting standards on fair value. The International Accounting Standards Board (IASB) defines fair value as the price that would be received for selling an asset or paid to transfer a liability, in an orderly transaction between market participants at the measurement date (White, 2008). According to Young (2008) fair value is the price that one would get in a reasonable exchange between knowledgeable parties. The focus is on exit price and not the entry price.

Previous studies have identified various benefits of FVA over historical cost. Edwards (1975) asserts that it is little comfort to know that the historic cost of every asset held by business firms has not changed since its acquisition. Young (2008) expresses that FVA is an evolution in financial reporting, which seeks to give users more timely and useful information. Barth (1994) notes that advocates of FVA believe it provides measures of assets, liabilities and earnings, which are more relevant.

According to Hitz (2005), the exact definition of the term fair value is only given at the level of the individual standards. The generalized definition has been used in the individual standards states that "Fair Value is the amount for which an asset could be exchanged, or a liability settled, between knowledgeable, willing parties in an arm's length transaction" (Hitz, 2005:1014). This describes fair value as the amount which could be transferred in a fictitious transaction between knowledgeable, willing parties under normal market conditions (arm's length transaction). Therefore, the fair value constitutes a hypothetical market price under idealised conditions but is not restricted to market value situations where current market quotations are available (Zacharski, Rosenblat, Wagner \& Teufel, 2007). Accounting standards discuss various ways of measuring fair value. The International Accounting Standard (IAS) 39 Financial Instruments: Recognition and Measurement requires an entity to use the most advantageous active market in measuring the fair value of a financial asset or liability when multiple markets exist (Seay \& Ford, 2010), whereas IAS 41 Agriculture requires an entity to use the most relevant market.

The international accounting standards board (IASB) provides the financial accounting standard (FAS) no.157 which embodies the development and enhancement of accounting reporting that caters for FVA (IASCF, 2007). These require an entity to use the principal market for the asset or liability (Willing, 1988). In absence of such, the entity uses the most advantageous market. Herz (2008) argues that a principal market is one in which the reporting entity would sell the asset or transfer the liability with the greatest volume and level of activity. He further asserts that the most advantageous market is one in which the reporting entity maximizes the amount received for the asset or minimizes the amount paid to transfer the liability, considering transaction costs.

Wilson (2010) identifies three valuation techniques of the FASB statement; namely the market approach, income approach, and cost approach, requiring use of a given technique when sufficient data is available and where appropriate. The market approach uses observable prices and other relevant information generated by transactions involving identical or comparable assets (Holmes \& Nicholls, 1988). The income approach converts future amounts to a single present value amount. The cost approach is based on the amount that would be currently required to replace the service capacity of an asset. In some instances, there is use of a single technique, whereas in others, multiple valuation techniques may be appropriate.

Yanez (2008) posited that observable inputs reflect assumptions used by market participants in pricing the asset or liability based on data obtained from sources independent of the reporting entity. On the contrary, unobservable inputs reflect the reporting entity's own assumptions developed based on best information available in the circumstances. The reporting companies must use fair value techniques that maximize observable inputs and minimize unobservable ones (Pannese \& DelFavero, 2010). The hierarchy determines the level of disclosure required in financial statements. According to White (2008), inputs are unobservable inputs based on the reporting entity's own assumptions about the assumptions that a market participant would use. These assumptions are those that are reasonably available, without undue cost or effort on the part of the reporting entity. These sentiments exclusively apply to the Zimbabwe situation.

Holt (2008) indicates that fair value is regarded as conceptually superior to historical cost values. It reflects open and competitive markets assessment of current economic conditions, showing all available information, up to the measurement date. Accounting on this basis will reduce anomalies in the existing mixed accounting approach. Ratcliffe (2007) explains the objective of new principles-based guidance is to improve balance sheet management, clarity and 
consistency of financial reporting. This is achieved by eliminating incidents in which related assets and liabilities are measured differently. Conversely, literature also identifies limitations of FVA. A byproduct of FVA, as discussed by Yanez (in Young 2008) is increased volatility. Due to subjective judgment, results derived will be questionable, and may lead to litigation. Rayman (2007) believes that FVA may be misleading or flawed. Botosan, Koonce, Ryan, Stone and Wahlen (2005) also considered research, which demonstrated that due to differences in interpretation of terms, if valuation information is seen as misleading, and taken to court, it would result in litigation costs.

Hitz (2005), states that the stewardship function is discharged through provision of a historical record. He stresses the contractual relationship between the reporting entity and those who provide resources. In addition the fair value option for financial assets and financial liabilities standard does not consider certain items (Seay \& Ford, 2010). For example, assets and obligations associated with pensions and other post-retirement benefit plans, financial assets and liabilities recognized under lease agreements, and more. This indicates that the international accounting standard no. 39 (IAS 39) may be incomplete. Such lack of guidance leads to inconsistencies in reporting practice. According to White (2008), FVA applies to jurisdictions with active secondary markets for financial instruments. Application of this standard in Zimbabwe is not wholly prudent. The inflationary economy simply does not have adequately qualified valuers; thus increased cost issues. Furthermore, use of fair values will make financial reporting more complex and less readily understood.

Possibly, the analytical worth of FVA is not considered high enough to warrant the cost of producing it (Seay \& Ford, 2010). Moreover, other advantages can only be realized if the method is widely practiced. According to Herz (2008), financial institutions now require more rigorous disclosures and thus, a greater number of assets are being carried at fair value. In Zimbabwe, lead is taken from the IASB. Thus, regulations already permit (and often direct) reporting entities to employ fair values.

\section{Methods}

Due to time constraints and difficulties in selecting specific users of financial reports, proxies were employed. The Old Mutual Unit Trust of Zimbabwe (OMT), Infrastructure Development Bank of Zimbabwe (IDBZ), the Zimbabwe Stock Exchange (ZSE) and the Bankers' Association of Zimbabwe (BAZ) acted as proxies for users. The four main accounting firms, AMG Global Chartered Accountants, Ernst \& Young (E\&Y), KPMG and Pricewaterhouse Coopers (PwC), acted as proxies for preparers. Face to face and telephone interviews were conducted

\section{Findings}

\subsection{Basic Understanding of FVA}

When it comes to defining 'fair value', preparers interpret it as the 'market price or market value', or simply as the 'price for which an item would be exchanged between a willing buyer and a willing seller' (Seay \& Ford, 2010). This indicates the need for consensus between willing buyers and willing sellers, in order for fair value to be established. One of the preparers emphasized FVA to be the recording of assets and liabilities at values in an open market. In such a market, there would be willing buyers and willing sellers who have no restrictions (such as, cash, price or legal constraints). In other words, fair value is the value that one would get in an active market. This is a difficulty in Zimbabwe, as only eightyone companies are listed on the stock exchange, and these companies engage in minimal trading. The preparers view FVA to be a broad topic, where focus is not only on the definition of the term but also on measurement, presentation and disclosure of assets, liabilities and equity in financial statements. Preparers referred to the definition of fair value in the International Financial Reporting Standards (IFRS) and opted to adopt this.

Two of the users define fair value as the value at which an item could be bought or sold in a current transaction between willing parties. Another user viewed it to be an estimate of the price an entity would realize if it were to sell an asset, or a price it would pay to relieve a liability. Fair values are seen as rational and unbiased estimates of potential market prices of commodities, based on factors such as scarcity, utility, and risk. Another user considered FVA to be about obtaining an estimate of the market value of an asset (or liability) for which there is no established market. In other words, it is about how an economy like Zimbabwe would determine the market prices of its assets and liabilities where there is no active market, except for shares and investment properties.

\subsection{Fair Value Accounting and the Zimbabwe Market}

In Zimbabwe, preparers decide what assets and liabilities are to be reported at fair values. They first refer to active 
markets to determine market values of financial assets. Reference is limited as ZSE is very small and caters for only eighty-one listed companies. Moreover, there is no active market for assets and liabilities apart from property development and shares. Therefore, the amount of trading is minimal and values obtained may not be representing the actual market values (Pannese \& DelFavero, 2010).

In the absence of an active market, reference is made to market prices of identical assets and liabilities of its competitors or similar industries. Since this requires judgment, preparers have to be cautious in deciding on what constitutes an appropriate identical asset or liability and which entity's price should be adopted for reporting. Since companies in Zimbabwe do not face rigorous competition and they differ in terms of size and operations, it is quite difficult to make comparisons. To allow for the use of fair values, the reporting entity would have to make the companies comparable by discounting selected values using some percentages. As a result, the fair value derived would be subjective and unreliable.

An independent valuation would be the third option. Since Zimbabwe does not have adequate skilled workmanship to provide valuations, expatriates would be needed. Multinational firms in Zimbabwe may also prefer to use their own valuers who are located in other countries. However, this approach would be very costly. The common approach is the use of valuation methods stated in IAS 39 and IFRS 7 Financial Instruments: Disclosures. Organisations could use the future maintainable earnings method, which projects future earnings by using discount rates to calculate the value of the investment. This is used by companies that have been operating profitably for some time. A business which has just started or a business that has been making losses would use the net asset backing method, where they can utilize their net assets to calculate fair values. These organisations could also use other methods, such as discounted cash flows or dividend earnings method.

In the absence of effective markets, one would also look at future cash flows. It is difficult to obtain reliable cash flow projections due to difficulty in predicting the economic and political stability in Zimbabwe. The Reserve Bank of Zimbabwe (RBZ) takes quite some time in releasing interest and inflation rates. Due to this delay, organisations are then required to predict and use their own discount rates. Thus, fair values are based on judgments or projections and are therefore quite subjective in nature. It then becomes difficult to rely on assumptions that have been used to determine fair values based on future cash flows or discounted cash flow methods.

In the absence of an active market or in the case where minimal trading takes place, an entity has the last resort to record its assets at cost, which is presumed to be the fair value. Statutory and private companies assume that costs are market values for investments that do not have any listed or exchange values. According to preparers, many organisations have adopted this approach in Zimbabwe. When asked for their preference of FVA, historical cost or a 'hybrid' method, preparers responded by referring to the reporting distinction between small and medium enterprises (SME's) and large companies in Zimbabwe. Zimbabwe has a hybrid system of reporting, which includes a combination of historical cost and FVA. Each entity has its own variation of the hybrid system. Hence, they account for assets and liabilities differently. Currently, micro and small enterprises are not necessarilty required to report under IFRS (Pannese \& DelFavero, 2010). Therefore, in most cases, their assets are recorded at historical cost. If SME's do opt to adopt IFRS, then they could use the 'deemed cost option' in which they could record their assets at deemed values at the beginning of the year and depreciate these assets at its deemed cost. SME which have investments in other organisations, such as shares, can classify these in different categories (specified in IAS 39) and use fair values where applicable.

Preparers are holding consultations with their clients and advising them on the merits of adopting FVA. This indicates that accounting firms want their clients to use FVA for financial reporting purposes. It benefits accounting firms in terms of higher fees (consultation, advisory and audit) and concurrently benefits users by providing more relevant information. However, it was noted that preparers are hesitant to report financial liabilities using FVA. They prefer to record these at contractual amounts due to lack of guidance and support from financiers. Furthermore, it is believed that users will not be able to comprehend values being reported or understand how it was derived. Additionally, if companies adopt the concept of recording financial liabilities at fair values and paying these liabilities at its contractual amounts on maturity dates, the financial reports would be perceived to be misleading.

Some preparers suggest that FVA should be industry based. That is, FVA should only be used by financial services, property and plant, manufacturing companies, real estate and insurance companies. It can also be used according to nature of business, type of ownership and type of users. However, a preparer added that if a rule applies, it has to apply generally. Comparisons will not be possible if organisations start to pick and choose. If assets are disclosed at two different measurement bases within one industry, the purpose of IFRS, to achieve comparability is defeated.

Users preferred to employ the hybrid system of reporting, in order to ensure a balance between reliability and relevance of information in financial reports. According to them, all items that must be reported at fair value should be done so, while other items can be reported at historical cost. Users also stated that full adoption of FVA will not be 
appropriate for small businesses, due to cost factors. Therefore, they believe that small businesses should be given the option of using either fair value or historical cost, and use fair value only in instances where users would benefit. Large companies, on the other hand, should use FVA and not be given any exceptions.

Given a list of assets and liabilities, users selected those they would like to see being reported at fair values (Table1). It can be observed that items such property, plant and equipment, investment properties, intangible assets, financial assets, biological assets, inventories, cash and cash equivalents, provisions, financial liabilities, DTA and DTL and minority interests are some elements that users want to see being reported at fair values. One user stated that all items in the balance sheet should in fact be reported at fair values. It will let users know what the elements are worth today rather than being misled through historical figures.

Table 1: List of Assets and Liabilities

\begin{tabular}{|l|c|c|c|c|}
\hline \multicolumn{1}{|c|}{ Item: } & User 1 & User 2 & User 3 & User 4 \\
\hline Property, plant and equipment & 67 & 17 & 21 & 39 \\
\hline Investment property & 73 & 29 & 42 & 34 \\
\hline Intangible assets & 71 & 28 & 35 & 9 \\
\hline Financial assets & 69 & 31 & 29 & 7 \\
\hline Investments accounted for using the equity method & 63 & 25 & 31 & 9 \\
\hline Biological assets & 31 & 4 & 23 & 11 \\
\hline Inventories & 49 & 9 & 23 & 7 \\
\hline Trade and other receivables & 57 & 6 & 1 & 0 \\
\hline Cash and cash equivalents & 13 & 3 & 6 & 3 \\
\hline Trade and other payables & 19 & 13 & 3 & 11 \\
\hline Provisions & 21 & 6 & 16 & 9 \\
\hline Financial liabilities & 63 & 13 & 27 & 16 \\
\hline Deferred tax liabilities (DTL) and deferred tax assets (DTA) & 14 & 7 & 11 & 5 \\
\hline Minority interest & 43 & 9 & 19 & 13 \\
\hline Issued capital and reserves attributable to equity holders of the parent & 7 & 17 & 2 & 8 \\
\hline
\end{tabular}

\subsection{Suggested Benefits of FVA}

Preparers stated that users are consulted in the standard setting process, that is, before exposure drafts are issued. Therefore, since users of the financial reports are driving the changes in standards, it should benefit them the most. In particular, reference was made to shareholders and potential investors. Fair value enables shareholders to know the value of their assets (shares) based on the current market prices and enables calculation of future estimates in an entity's current financial report (as opposed to historical cost). It also enables them to make an assessment of what the proceeds from disposal would be, if their assets were disposed of in an orderly fashion. Using fair value also ensures industry-wide and cross-country comparison of financial statements and enables timely feedback. In regards to prospective investors, they will have better understanding of what the value of an entity is, and this will help them assess their potential returns.

IFRS 7 requires companies to disclose the fair value of some assets that are recorded at historical cost in the balance sheet. This benefits all users in their search for more useful information to make better decisions, and having financial gains rather than losses. This is especially so if the organisations operate in shares and property investment markets (ICAEW, 2008). One of the users explained that benefits will depend on the type of entity, what the user want and their level of understanding. The interviewee stated that if users do not understand the concept of FVA, financial reports produced will not be of any benefit to them. According to users, the shareholders, financiers and regulatory bodies will benefit. Under FVA, financiers will be given an opportunity to monitor the level of profit growth, as well as capital growth. FVA requires revaluation of assets, leading to changes in capital values and hence affecting growth. All financial institutions in Zimbabwe come under the scrutiny of RBZ. Fair value reporting will help them in determining the level of investments and growth in the economy. RBZ places prudential requirements on financial institutions. As such, if these organisations maintain their investments at cost, RBZ will not know the worth of their investments and will also not be 
able to assess whether the organisations are adequately covered.

The major benefit of FVA is that it provides useful and relevant information for decision-making. Financial statements will show the market value of the business, and as such, despite a decrease in reliability, it will rank high in terms of relevance. It is felt that regardless of this tradeoff, the qualitative factor of relevance will surely assist users.

\subsection{Market Interpretation of the Limitations of FVA}

According to the preparers, the major limitation associated with FVA in Zimbabwe is the issue of costs. This is in terms of getting expatriates and specialists to perform valuations and prepare reports. For example, insurance companies (which require actuaries) will have to hire expatriates since Zimbabwe does not have such specialists. Also, the need for training or hiring knowledgeable and qualified professionals will increase costs. The accounting firms will have to provide consultation services to help their clients understand FVA. In contrast, a preparer argues that cost does not seem to be a major limitation as IAS 36 Impairment of Assets already requires that organisations do an impairment test. Therefore, in some way or the other, businesses are exposed to these costs.

Organisations which have greater levels of assets and liabilities tend to incur higher costs. The additional costs hinder full compliance with FVA. For example, it is approximated that The National University of Science and Technology (NUST) will have to spend around \$6 million in valuing its assets. This is a huge sum to expunge on valuations alone. Thus NUST may not be in favor of that, and may fail to comply in totality. A preparer suggests that FVA should be mandatory for some organizations in particular, by looking at factors such as size, nature of business, users of the entity`s financial reports, and so forth. In this way, many small organizations will be saved from the cost burden.

In addition, there are practical difficulties, particularly in a small country like Zimbabwe, where only eighty-one companies (with minimal trading activities) are listed on the ZSE. Organisations may not be able to comply fully with fair value reporting due to the absence of an active market. Furthermore, Zimbabwe has a very vulnerable and changing economy. Due to the economic and political situation, specialists are quite reluctant to provide valuations. FVA has also been criticized for being subject to managerial discretion and for not having properly defined valuation methods. This allows preparers to use their judgments in determining the factors or elements being used in the valuation models, and therefore, making it subjective. Valuers will have differing opinions on factors involved in these models. For example, deciding on appropriate discount rates (Herz, 2008). This could lead to under-or over-valuation of assets, leading to preparation of misleading reports. This could potentially result in litigation costs, if taken to court. Thus, financial reports will have to be thoroughly verified, before being made accessible to users. This will affect timeliness in reporting.

The choice between historical cost and FVA results in a tradeoff between reliability and relevance of financial information. Since these qualities are mutually exclusive, increasing relevance of information compromises its reliability and vice versa. This creates a problem if reported information does not "provide useful information to financial statement users in making economic decisions" (IASB, 2008). Users also expressed their concerns in regards to increased costs involved in adopting FVA. Also, most businesses in Zimbabwe are family owned or private companies. In such cases, fair value reporting may not be relevant, as it does not bring in incremental revenues. Since many organizations in Zimbabwe are small, it may be impractical and a cost burden for them to comply with FVA.

In addition, users also believe that valuation techniques adopted by businesses in Zimbabwe may not provide them with reliable information, even though it may provide relevant information to some extent. Reliability of fair values are questionable, as this information is subjective. Intentional or unintentional management bias may result in inappropriate measurement and misstatements in earnings and equity capital. Even when valuations are done and reports are disseminated to users, there will be volatility in earnings. There will also be problems in terms of understandability. If users are not familiar with FVA, how it is measured and the reasons for applying this concept, then eventually such reporting will be of little or of no value to them. Users will have to educate and familiarize themselves with FVA, to gain better understanding of financial reports.

\subsection{Perceived Role of Financial Reporting}

Users uphold that financial reporting has a decision-making role. Relevant information will guide users in making informed and transparent decisions. Some users added that financial reporting also fulfills stewardship, accountability, transparency and comparability roles. Financial reporting provides a record of how funds and resources, contributed by the users, have been utilized by the entity. Comparability is achieved when users evaluate details within financial reports, and compare these across businesses of similar nature. According to users, generally, FVA fulfils stewardship, decision making and valuation roles. It fulfills the stewardship role by making directors answerable to shareholders. It also fulfills 
the decision making role as shareholders will be able to make decisions, such as, whether they should continue their shareholding, of realize or sell the shares based upon the realization or disposal proceeds.

However, one user believes that reporting under FVA will fulfill roles depending on the nature of the business and users of its financial reports. He states that for private companies, FVA will not be useful since directors, shareholders and preparers are basically family members who have access to all information. As such, FVA will not produce any new information, but only contributes to increasing costs. However, for a public company, FVA will fulfill the role of decisionmaking and stewardship. In addition, firms through use of valuation models will be able to take into account relevant data, such as current economic forecasts and general market conditions to measure fair value. Hence, FVA fulfills the valuation role as well.

\subsection{Perceptions about the Prominence of FVA}

Both preparers and users agree that FVA will gain prominence and in future, will remain as part of the accounting standards. One preparer stated that although historical cost has served well, it has many limitations, particularly regarding valuation of assets. Recording of liabilities are fine under both historical cost and fair value methods, since they are stated at their contractual amounts. Assets, however, are held for longer periods of time and their values are quite volatile. Thus, there is hope that fair value will hold ground and replace historical cost.

Even though reliability is compromised when it comes to projecting risks, the use of chartered accountants and other professionals will be able to deal with the limitations of FVA. Eventually, the boards of companies may develop competencies in reviewing methods used to arrive at fair values. Valuation techniques could be revisited and reviewed. In this manner, confidence in FVA will increase and so will the demand for reporting under this method (HKICPA, 2008). FVA has been present in the accounting standards for quite some time now. For example, impairment testing is not a new concept. There are possibilities that FVA guidelines may change slightly but it will definitely remain in future. IFRS's require FVA. Therefore, as more organisations start adopting IFRS's, the market for FVA will expand and in this manner, it will gain prominence and survive in future.

\subsection{Alternatives to FVA}

From the interviews, it was noted that currently there are no alternatives to FVA. Since Zimbabwe does not have adequate resources to produce its own standards, there is not much choice but to rely on international standards. However, the Institute of Chartered Accountants in Zimbabwe (ICAZ) and the Zimbabwe Institute of Accounting Technicians (ZAAT) have tried to seek provisions. That is, if there are practical difficulties associated in determining accurate fair values, organisations are allowed resort to historical cost measures. For example, where organisations do not have skilled staff or where they have insufficient funds to hire experts, they could report assets and liabilities at historical cost.

\section{Concluding Remarks}

Preparers and users have similar understanding of FVA. Both agree that financial reports should be in line with either historical cost or FVA, depending on size, nature and users of financial reports. However, where one sees the need for relevant information, there is preference of FVA over historical cost accounting. Users perceive the roles of financial reports as being mostly for decision-making and stewardship purposes. They want business operators in Zimbabwe to report as many of their assets and liabilities at fair values, in order to prevent being misled like Enron's users were.

Due to time and resource constraints, this paper is based on the views of eight interviewees. This may not be a true representative of views of preparers and users Zimbabwe-wide. To be fully conclusive, further research is needed, using a greater sample size. However, it is agreed that FVA has its pros and cons. It will tend to provide more disclosures, than what is generally provided for under historical cost accounting. There will be limitations in terms of understandability, cost, reliability of information, volatility in earnings and timeliness. There are many valuation techniques being used, indicating that FVA has technical and practical difficulties in a small economy like Zimbabwe. It has yet to develop the most appropriate and suitable way of determining fair values.

It is essential that accounting bodies (such as ICAZ ) create awareness, provide training and give guidance to preparers. Organisations should be given the opportunity to resort to historical cost where they foresee practical difficulties in obtaining fair values. At this stage, differential reporting is preferred, with full compliance of FVA further in the future. Currently, no one sees any alternatives to FVA and many believe that with daily modifications being done, FVA 
will survive (Kaplan, 2011). Therefore, it seems that even a country like Zimbabwe is willing to adopt FVA, regardless of its limitations. This is for the benefit of users and to fall in line with other countries, in order to achieve harmonization in reporting.

\section{References}

Barth, M. (1994). Fair Value Accounting: Evidence from Investment Securities and the Market Valuation of Banks. The Accounting Review, 69(1) 1-25.

Bernanke, B. \& Gertler, M. (1999). Monetary Policy and Asset Price Volatility. Federal Reserve Bank of Kansas City, Economic Review, Fourth Quarter, (4) 17-51

Botosan, C., Koonce, L., Ryan, S., Stone, M., \& Wahlen, J. (2005). Accounting for Liabilities: Conceptual Issues, Standard Setting, and Evidence from Academic Research. Accounting Horizons, 19(3), 159-186.

Edwards, E. (1975). The State of Current Value Accounting. The Accounting Review, 50(2), 235-245.

Herz, R. (2008). Dynamic assets do not fit in passive vehicles. Fair Value Roundtable. Journal of Accountancy, (1), 60-70

Hitz. J.-M. (2005). Fair value in der IFRS-Rechnungslegung - Konzeption, Inhalt und Zweckmäßigkeit. Die Wirtschaftsprüfung, 58(18), 1013-1027.

Holmes, S \& Nicholls, D. (1988). An analysis of the use of accounting information by Australian small business. Journal of Small Business Management, 26(2):57-68.

Holt G (2008). IFRS for SMEs India: Student Accountant. Kaplan-ACCA. London.

Hong Kong Institute of Certified Public Accountants (HKICPA). (2008). Small and Medium-sized Entity Financial Reporting Framework and Financial Reporting Standard. HKICPA, Hong Kong

Institute of Chartered Accountants in England and Wales (ICAEW). (2008). A blueprint for SME financial reporting to accelerate economic recovery: The Accounts Review Solution IN: Accountancy Age, 101-123.

Institute of Chartered Accountancy Zimbabwe (ICAZ). (2010). Small and Medium-sized Entities news. Available on www.icaz.org.zw, retrieved 6 Sept 2010).

International Accounting Standards Committee Foundation (IASCF). (2007). Exposure Draft of a proposed IFRS for SMEs. February 2007. IASC Foundation Pubs. London.

Kaplan, R. (2011). Accounting scholarship that advances professional knowledge and practice. The Accounting Review, 86(2), 367-383

Pannese, D., \& DelFavero, A. (2010). Fair value accounting: Effect on the auditing profession. Journal of Applied Business Research, 26(3), $43-50$

Ratcliffe, T. (2007). The Finer Points of Fair Value. Journal of Accountancy, 204(6), 58-61.

Rayman, R. (2007). Fair Value Accounting and the Present Value Fallacy: The Need for an Alternative Conceptual Framework. British Accounting Review, 39(3), 211-225.

Seay, S., \& Ford, W. (2010). Fair presentation- An ethical perspective on fair value accounting pursuant to the SEC study on mark-tomarket accounting. Journal of Legal, Ethical and Regulatory Issues, 13(1), 53-66

White, M. (2008). Fair Value Accounting. Journal of the Zimbabwe Institute of Accountants, 23(2), 18-21.

Willing, K. (1988). Learning styles in adult migrant education. Adelaide, Australia: NCRC/AMEP.

Wilson, B. (2010). The Proliferation of IFRS: One Global Set of Accounting Standards. Retrieved November 21, 2013, from Hedge Accounting Matters Web site: http://hedgeaccountingmatters.com/posts/the-proliferation-of-ifrs-one-global-set-of-accountingstandards.

Yanez, A. jr. (2008). A litigator's perspective, increasing accounting litigation. Fair Value Roundtable. Journal of Accountancy, (1), 60-70

Young, M. (2008, June), Standard setters, preparers and auditors analysis arising from challenges from subprime meltdown. Fair Value Roundtable. Journal of Accountancy, (1), 60-70.

Zacharski, A., Rosenblat, A., Wagner, E. \& Teufel, A. (2007). FASB Statement on Fair Value Measurements. Journal of Investment Compliance, 8(1), 36-39. 